\title{
Correlation between the Microstructure of Galvannealed Coatings and the Defoliation during Press Forming
}

\author{
Moon-Hi HONG \\ Cold-Rolling Department, POSCO, Kwang-yang, 545-090, S. Korea. E-mail: moonhihong@posco.co.kr
}

(Received on November 19, 2004; accepted on March 4, 2005)

\begin{abstract}
The defoliation properties of galvannealed coating, so-called powdering and flaking, in a commercial continuous galvanizing line were investigated by scanning electron microscopy, X-ray diffraction, a roughness profiler and deep drawing test. Both aluminum content in molten zinc and galvannealing temperature were found to be critical factors controlling the microstructure and mechanical properties of galvannealed coatings. Below $0.135 \mathrm{wt} \% \mathrm{Al}$, the coating surface was composed of a mixture of granular $\delta_{1 \mathrm{p}}$ and columnar $\zeta$ phases, while, above $0.155 \mathrm{wt} \% \mathrm{Al}$, the coating surface contained the mixture of granular $\delta_{1 \mathrm{p}}$ and pan-cake $\delta_{1 \mathrm{k}}$ phases. The appearance of brittle $\delta_{1 \mathrm{k}}$ phase approximately $10 \mu \mathrm{m}$ in size can account for the high amount of defoliation during deep drawing test. The formation of relatively ductile $\zeta$ phase and thin $\Gamma$ phase contributes to improve the press formability. The optimization of the surface microstructure controlling the ratio of granular $\delta_{1 \mathrm{p}}$ and columnar $\zeta$ phases was important to reduce the powdering.
\end{abstract}

KEY WORDS: galvannealing; powdering; flaking; Al content; Fe-Zn intermetallics.

\section{Introduction}

Galvanized (GI) steel sheets, which consist of pure zinc, generally exhibit superior corrosion resistance compared with the cold-rolled sheets. GI sheets have been widely used in various fields such as automotives, constructions and appliances. However, the electrode tip life-time in spotwelding decreases dramatically from 20000 for cold-rolled steel sheets to only 600 for GI steel sheets because of the transformation of copper in electro tip into brass by reaction with $\mathrm{Zn}$ in the coating. ${ }^{1,2)}$ To cope with this problem, hot dip galvannealed (GA) steel sheets, in which Fe of the steel substrate diffuses into the upper coating layer so as to be alloyed with $\mathrm{Zn}$ during a gas or electrical-type heating has been developed. The GA coating is composed entirely of the five rather brittle $\mathrm{Fe}-\mathrm{Zn}$ intermetallic phases from the coating/substrate interface, i.e., $\Gamma, \Gamma_{1}, \delta_{1 \mathrm{k}}, \delta_{1 \mathrm{p}}$ and $\zeta$ phases. ${ }^{3-7)}$ Among them, $\delta_{1 \mathrm{p}}$ is the major constituent of the coating (about $80 \%$ in volume). GA coating consisting of $\mathrm{Fe}-\mathrm{Zn}$ intermetallic compounds improves the electrode tiplife time up to 4000 times. $^{1,2)}$ However, the brittle $\mathrm{Fe}-\mathrm{Zn}$ compounds, especially $\Gamma$ (bcc) and $\Gamma_{1}$ (fcc), may give rise to detrimental problem during press forming, where defoliation of coating, i.e., powdering and flaking, occurs. ${ }^{8,9)}$ Since powders spalled-off from GA coating have higher Vickers micro-hardness $\left(\mathrm{H}_{\mathrm{v}}, 300-500\right)$ in comparison with the steel substrate $\left(\mathrm{H}_{\mathrm{v}}, 100\right)$, they can easily adhere to the press die and causes various problems both on the die and the pressed panel. ${ }^{10)}$ Another detrimental effect to be considered is the formation of pinhole of the paint layer during subsequent electroplating for automotive product process. During hot dipping of steel in zinc bath through molten zinc containing $0.12-0.18 \mathrm{wt} \% \mathrm{Al}, \mathrm{Fe}-\mathrm{Al}$ inhibition layer with $200-400 \mathrm{~nm}$ thick is formed preferentially at the molten zinc/substrate interface. It has shown that inhibition layer consists of $\mathrm{Fe}_{2} \mathrm{Al}_{5}$ (orthorhombic) and $\mathrm{Fe}_{3} \mathrm{Al}\left(\mathrm{DO}_{3}\right.$ ) particles and retards the formation of the $\mathrm{Fe}-\mathrm{Zn}$ intermetallic. ${ }^{112)}$ Harvey and Mercer showed by transmission electron microscopy that inhibition layer is composed mostly of $\mathrm{Fe}_{2} \mathrm{Al}_{5}$ particles containing $10-15 \mathrm{wt} \% \mathrm{Zn} .{ }^{13)}$ Morimoto et al. investigated the crystallographic relationship between steel substrate and $\mathrm{Fe}_{2} \mathrm{Al}_{5}$ on various steel and concluded that the chemical composition of steel substrate affects the microstructure of inhibition layer. ${ }^{11,12)}$ In particular, an addition of $\mathrm{P}$ in Ti-added interstitial free (IF) steel favored the formation of the thick $\mathrm{Fe}_{2} \mathrm{Al}_{5}$ layer and retarded the $\mathrm{Fe}-\mathrm{Zn}$ reaction. ${ }^{14)}$ It is also shown that the thickness of inhibition layer increased by increasing the $\mathrm{Al}$ content in zinc bath. However, up to date, many studies have been focused on the GI and/or GA steel sheets manufactured by laboratory hot dip simulator. And few studies has been carried out for the effect of $\mathrm{Al}$ content in zinc bath and galvannealing temperature on the microstructure and mechanical properties of GA steel sheets produced by industrial continuous galvanizing line (CGL). In the present study, the correlation between microstructure and powdering and/or flaking properties of GA coating in commercial CGL were investigated by optical microscopy (OM), X-ray diffraction, scanning electron microscopy (SEM), roughness profiler, deep drawing and U-bend tests. Various Al contents and galvannealing temperatures were used. 


\section{Experimental Procedures}

The GA coatings investigated in the present study were prepared from the industrial CGL equipped with extensive strip cleaning section, all radiant tube annealing furnaces, pre-melting and two pots zinc system and induction-type galvannealing furnace. ${ }^{15}$ ) The cleaning section contains serials of aqueous alkaline dipping tank, abrasive brushing machine, pickling and electrolytic cleaning tank. Table 1 shows the chemical compositions of the $\mathrm{Ti}+\mathrm{Nb}$-added IF steel sheets used in present study, where a small amount of carbon and nitrogen were precipitated as $\mathrm{TiC}, \mathrm{NbC}$ and $\mathrm{TiN}$ nano-particles while steel sheets were elongated. The GA coatings were produced at galvannealing temperatures between 480 and $620^{\circ} \mathrm{C}$ with a line speed of approximately $80-100 \mathrm{~m} / \mathrm{min}$. Al content in the zinc bath was varied between 0.125 and $0.165 \mathrm{wt} \%$ and the zinc bath temperature was between 448 and $457^{\circ} \mathrm{C}$. More than 100 samples for automotive panels with $0.6-1.0 \mathrm{~mm}$ thick and the coating weight of $45-60 \mathrm{~g} / \mathrm{m}^{2}$ per each side were prepared. Al content in zinc bath and $\mathrm{Fe}, \mathrm{Zn}$ and $\mathrm{Al}$ compositions of GA coating were analyzed by inductively coupled plasma (ICP) method. The plan-view and cross-sectional microstructures were investigated using a Cambridge SEM combined with an energy dispersive X-ray spectroscopy (EDS). To reveal the precise thickness of $\Gamma$ layer, GA coating was mounted in the plastic mold, polished and, finally, etched using the $1 \% \mathrm{HCl}$ solution for $40 \mathrm{~s}$. Deep drawing and U-bend tests were adopted for clarifying the correlation between the microstructure and defoliation of GA coating. Figure 1 shows

Table 1. Chemical composition (wt\%) of the substrate sheet steel used in the galvannealing process.

\begin{tabular}{|c|c|c|c|c|c|c|}
\hline $\mathrm{C}$ & $\mathrm{Mn}$ & $\mathrm{Si}$ & $\mathrm{P}$ & $\mathrm{S}$ & $\mathrm{Ti}$ & $\mathrm{Nb}$ \\
\hline$\leq 0.004$ & $\leq 0.2$ & $\leq 0.02$ & $\leq 0.015$ & $\leq 0.015$ & $\leq 0.040$ & $\leq 0.15$ \\
\hline
\end{tabular}
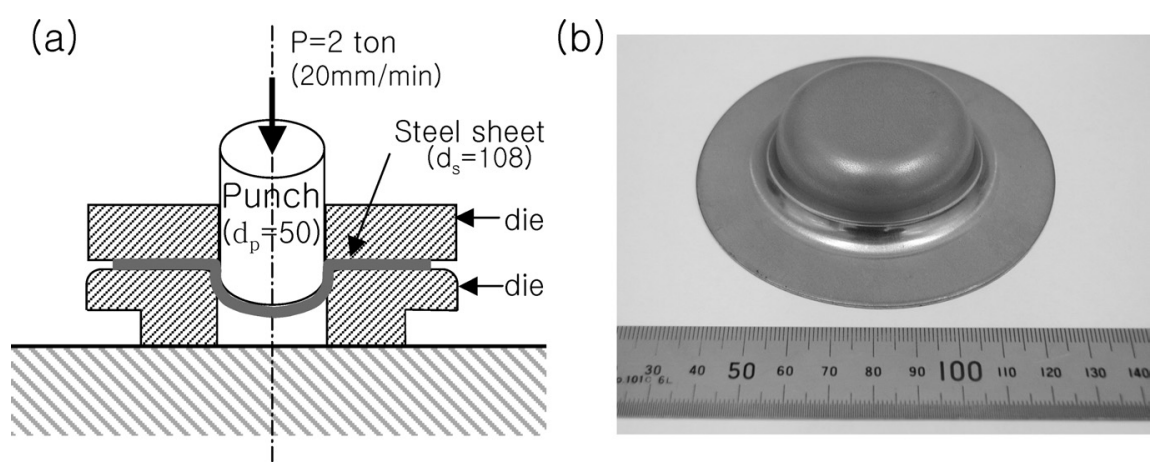

Fig. 1. Schematic illustration of (a) deep drawing dies and (b) the photograph of deformed sample.

(a)

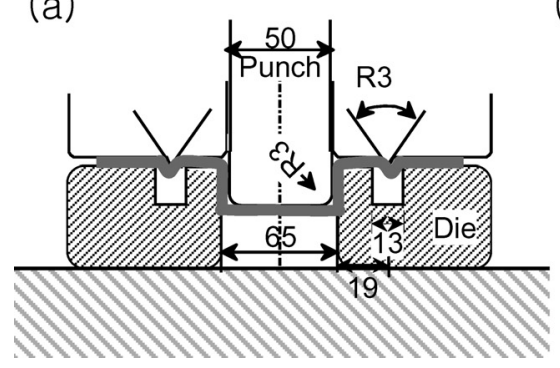

the schematic illustration of (a) deep drawing dies and (b) the photographs of deformed sample. The amount of powdering was evaluated as difference in the weight of the sample before and after deep drawing test. On the other hand, the correlation between GA coating microstructure and flaking properties was characterized by the U-bend test. Figure 2 shows the schematic illustration of (a) U-bend dies and (b) the photographs of U-type deformed sample. The flaking indexes were divided into five grades based on the amount of spalled-off GA coating after U-bend test, where 1st grade indicates the no defoliation of the coating and 5 th grade is the worst case.

\section{Results and Discussion}

Figure 3 shows the effect of galvannealing temperature (a) on the amount of powdering and (b) on the Fe content of GA coating, respectively. In Fig. 3(a), it is evident that the powdering can be expressed in terms of galvannealing temperature. Below $525^{\circ} \mathrm{C}$, the powdering was a substantially acceptable value for press forming, namely $10-30 \mathrm{mg} / \mathrm{m}^{2}$. Between 550 and $600^{\circ} \mathrm{C}$, its value increased to the highest value of $90 \mathrm{mg} / \mathrm{m}^{2}$ with increasing galvannealing temperature. Here, it should be mentioned that the peritectic temperature of the rather ductile $\zeta$ phase in the $\mathrm{Fe}-\mathrm{Zn}$ binary system is $530^{\circ} \mathrm{C}$. ${ }^{3)}$ So, it is expected that brittle $\delta_{1 \mathrm{k}}$ and thick $\Gamma$ phase layers should be preferentially formed in GA coating when galvannealing is performed above $550^{\circ} \mathrm{C}$. It has been generally believed that there exists linear relationship between galvannealing temperature and Fe content in GA coating produced by laboratory simulator at a constant Al content in zinc bath. ${ }^{16,17)}$ However, as shown in Fig. 3(b), this is not the case for the GA coating produced by industrial CGL when Al content varies in a range between 0.125 and $0.165 \mathrm{wt} \%$. This can be explained by the fact that varia-

Fig. 2. Schematic illustration of (a) U-bend dies and (b) the photograph of U-type deformed sample. 
(a)

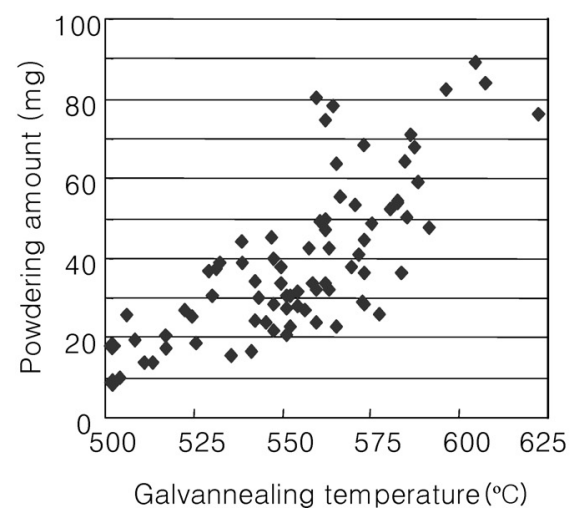

(b)

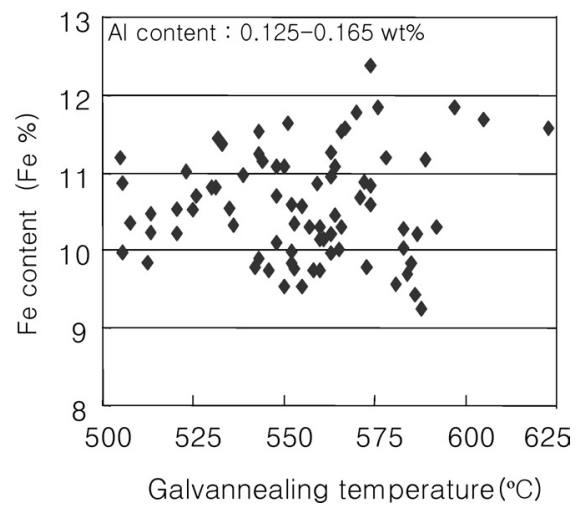

Fig. 3. Effect of galvannealing temperature (a) on the amount of powdering and (b) on the Fe content of GA coating, respectively.

(a)

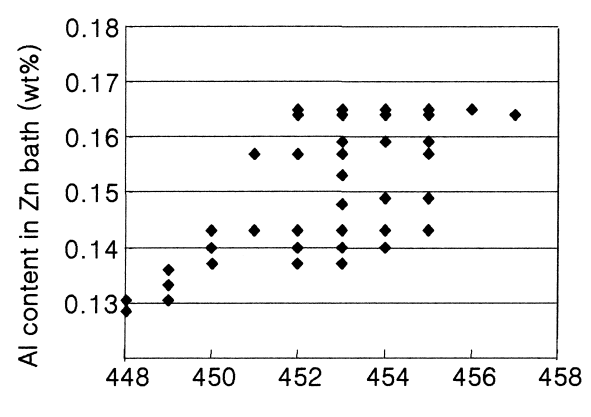

Zn bath temperature $\left({ }^{\circ} \mathrm{C}\right)$ (b)

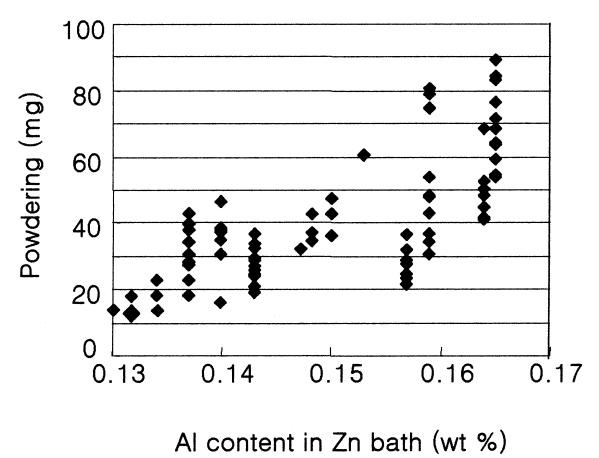

(c)

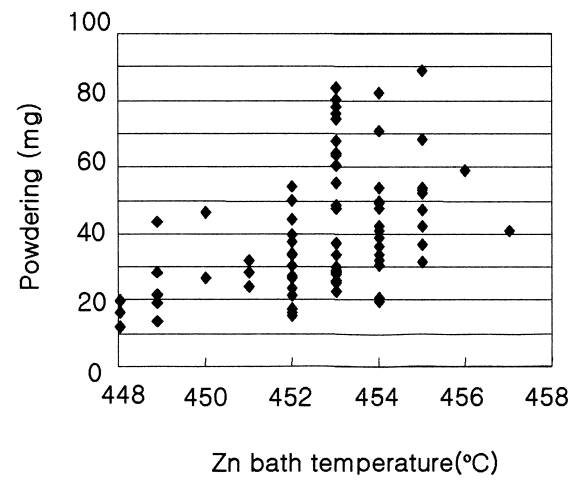

Fig. 4. The correlation between (a) Al content and temperature of zinc bath, (b) Al content and the powdering properties and (c) temperature of zinc bath and the powdering properties, respectively.

tion of the $\mathrm{Fe}-\mathrm{Al}$ inhibition layer thickness formed at the initial stage of galvanizing process in terms of Al content in zinc bath affects the nucleation and growth kinetics of $\mathrm{Fe}-\mathrm{Zn}$ intermetallics. By increasing the $\mathrm{Al}$ content, rather thick and dense inhibition layer formed at the molten zinc/substrate interface retards the $\mathrm{Fe}-\mathrm{Zn}$ reaction.

Figure 4 shows the correlation between (a) Al content and temperature of zinc bath, (b) Al content and the powdering properties and (c) temperature of zinc bath and the powdering properties. Figure 4(a) indicates that the deviation and/or scatter of the data points of $\mathrm{Al}$ content in zinc bath is large when the bath temperature is above $452^{\circ} \mathrm{C}$. $\mathrm{Al}$ content linearly increased between $448^{\circ} \mathrm{C}$ and $452^{\circ} \mathrm{C}$ and it was saturated above $452^{\circ} \mathrm{C}$. This can be well explained by assuming that the solubility of $\mathrm{Al}$ in zinc bath increases with increasing the bath temperature. $\mathrm{Fe}-\mathrm{Al}-\mathrm{Zn}$ dross particles floating in the zinc bath should contribute to the source for Al. Note that the Al content used in Fig. 4 is the measured $\mathrm{Al}$ and/or total $\mathrm{Al}$ containing both an effective $\mathrm{Al}$ in $\mathrm{Fe}-\mathrm{Zn}-\mathrm{Al}$ solution and non-effective $\mathrm{Al}$ in $\mathrm{Fe}-\mathrm{Zn}-\mathrm{Al}$ dross particles. ${ }^{18)}$ The samples shown in Fig. 4 contained the Fe$\mathrm{Al}-\mathrm{Zn}$ dross particles which does not directly affect the formation of $\mathrm{Fe}-\mathrm{Al}$ inhibition layer. However, there was no difference between effective and measured $\mathrm{Al}$ content when the solubility of $\mathrm{Fe}$ in zinc bath is below $0.04 \mathrm{wt} \%$ as measured in the present study. ${ }^{19)}$ To minimize the scatter of the composition due to the difference of sampling locations, all samples obtained from the center of the bath $300 \mathrm{~mm}$ apart from the strip and 350-550 $\mathrm{mm}$ in depth. Figure 4(b) shows the correlation between powdering and $\mathrm{Al}$ content in the zinc bath. Below $0.145 \mathrm{wt} \%$, powdering results were less than $40 \mathrm{mg} / \mathrm{m}^{2}$. In contrast, above $0.155 \mathrm{wt} \%$, powdering properties became poorer, i.e., $90 \mathrm{mg} / \mathrm{m}^{2}$. Generally, by increasing the $\mathrm{Al}$ content in zinc bath, rather thick and dense $\mathrm{Fe}-\mathrm{Al}$ inhibition layer is formed at the molten zinc/substrate interface. High Al content should suppress the diffusion reaction between $\mathrm{Fe}$ and $\mathrm{Zn}$ atoms which is leading to the preferential formation of ductile $\zeta$ phase. Ductile $\zeta$ phase in GA coating should improve powdering resistance. However, GA coating tested in the present study showed the opposite result, i.e., the amount of powdering increased with increasing $\mathrm{Al}$ content in zinc bath. This should be explained by the fact that the present study has been carried out using an industrial CGL instead of a laboratory hot dip simulator, i.e., galvannealing temperature has to be increased to produce the commercial GA sheet steels. In the case of industrial CGL, the under-alloying of GA coating is observed, especially, at high $\mathrm{Al}$ content with lower galvannealing temperature. Here, under-alloying means that the surface of galvannealing coating appears as silver color instead of conventional gray color because of the retardation of the $\mathrm{Fe}-\mathrm{Zn}$ alloy reaction. From the above results, it can be said that microstructure and mechanical properties of GA coating depend on Al content, galvannealing temperature and temperature of zinc bath.

Figures 5(a) through 5(f) show SEM micrographs ob- 


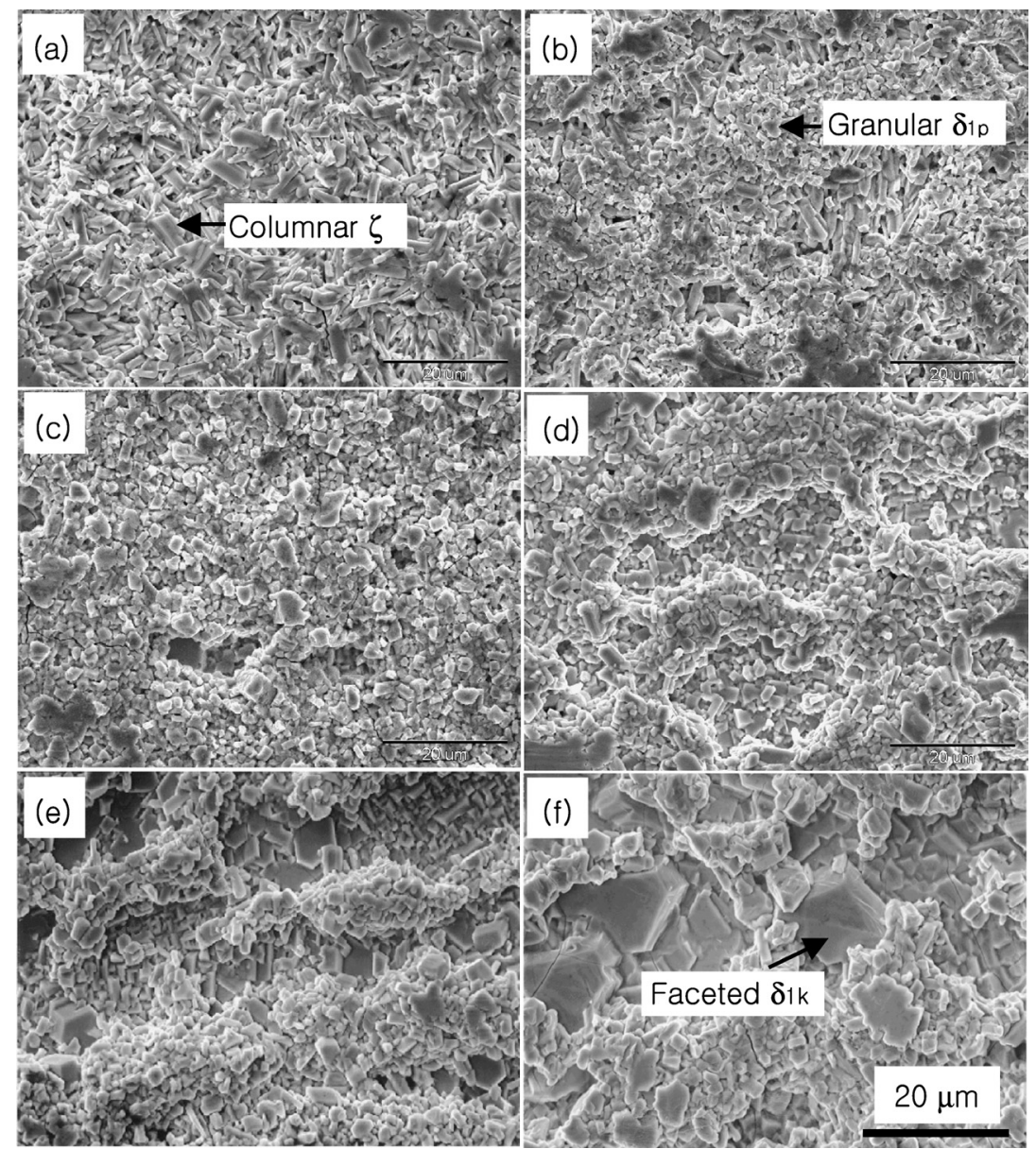

Fig. 5. SEM micrographs observed from the GA coating surface as the functions of Al content and galvannealing temperature; i.e., (a) $0.125 \mathrm{wt} \% \mathrm{Al}$ and $485^{\circ} \mathrm{C}$, (b) $0.135 \mathrm{wt} \% \mathrm{Al}$ and $510^{\circ} \mathrm{C}$, (c) $0.145 \mathrm{wt} \% \mathrm{Al}$ and $525^{\circ} \mathrm{C}$, (d) 0.155 $\mathrm{wt} \% \mathrm{Al}$ and $540^{\circ}$, (e) $0.160 \mathrm{wt} \% \mathrm{Al}$ and $560^{\circ} \mathrm{C}$ and (f) $0.165 \mathrm{wt} \% \mathrm{Al}$ and $605^{\circ} \mathrm{C}$, respectively.

served on the GA coating surfaces as the functions of Al content and galvannealing temperature. Samples were prepared at the conditions of (a) $0.125 \mathrm{wt} \% \mathrm{Al}$ and $485^{\circ} \mathrm{C}$, (b) $0.135 \mathrm{wt} \% \mathrm{Al}$ and $510^{\circ} \mathrm{C}$, (c) $0.145 \mathrm{wt} \% \mathrm{Al}$ and $525^{\circ} \mathrm{C}$, (d) $0.155 \mathrm{wt} \% \mathrm{Al}$ and $540^{\circ} \mathrm{C}$, (e) $0.160 \mathrm{wt} \% \mathrm{Al}$ and $560^{\circ} \mathrm{C}$ and (f) $0.165 \mathrm{wt} \% \mathrm{Al}$ and $605^{\circ} \mathrm{C}$, respectively. Below $0.135 \mathrm{wt} \%$, in Figs. 5(a) and 5(b), surface of GA coating consisted of the mixture of columnar and granular phase. $\mathrm{X}$-ray results showed that they are $\zeta$ and $\delta_{1 \mathrm{p}}$ phase, respectively. It is known that the columnar $\zeta$ phase is the predominant surface micro-structure in Fig. 5(a) where GA coating is produced at lower $\mathrm{Al}$ content and galvannealing temperature. By increasing $\mathrm{Al}$ content and galvannealing temperature, in Fig. 5(b), the $\delta_{1 \mathrm{p}}$ phase covered most of the GA coating surface and few $\zeta$ phase could be visible. In the Al content between $0.145 \mathrm{wt} \%$ and $0.155 \mathrm{wt} \%, \zeta$ phase completely disappeared and GA coating surface was mostly occupied by granular $\delta_{1 \mathrm{p}}$ phase. Above $0.160 \mathrm{wt} \%$, in Figs. $5(\mathrm{e})$ and 5(f), faceted and/or pan-cake phase with 10-15 $\mu \mathrm{m}$ in size was readily observed as indicated by arrow together with granular $\delta_{1 \mathrm{p}}$ phase. SEM/EDS and X-ray results showed that faceted phase is rather brittle $\delta_{1 \mathrm{k}}$ phase with higher $\mathrm{Fe}$ content compared with granular $\delta_{1 \mathrm{p}}$ phase. At $0.165 \mathrm{wt} \% \mathrm{Al}$ and galvannealing temperature at $605^{\circ} \mathrm{C}, \delta_{1 \mathrm{k}}$ phase mostly covered the GA coating surface. The surface micrographs, below $0.145 \mathrm{wt} \%$, clearly demonstrated the much smooth characteristic in comparison with the GA coating produced above $0.155 \mathrm{wt} \% \mathrm{Al}$ where high density of craters are readily observed.

Figures 6(a) through 6(f) show the two-dimensional roughness profiles measured from the GA coating surface shown in Figs. 5(a) through 5(f). Below $0.145 \mathrm{wt} \% \mathrm{Al}, R_{\mathrm{a}}$ (mean value) was measured in a range between $0.75-0.83 \mu \mathrm{m}$. It is within a reasonable value required by automotive makers, namely below $1.0 \mu \mathrm{m}$, for electro-plating and others. Above $0.150 \mathrm{wt} \% \mathrm{Al}, R_{\mathrm{a}}$ was in a range between $1.22-1.37 \mu \mathrm{m}$. It is quite high in comparison with the samples prepared by low $\mathrm{Al} \%$ content. From this fact, it is known that the desirable $R_{\mathrm{a}}$ should be achieved below 0.145 $\mathrm{wt} \% \mathrm{Al}$ and that is the reason why the $\mathrm{Al}$ content in zinc bath has to be maintained below $0.145 \mathrm{wt} \% \mathrm{Al}$ in the industrial galvannealing process. Above $0.150 \mathrm{wt} \%$, thick $\mathrm{Al}$ inhibition layer causes the rather inhomogeneous reaction between $\mathrm{Zn}$ and $\mathrm{Fe}$ atoms. As a result, many craters as shown in Figs. 5(d)-5(f) were formed on GA coating surface and resulted in the high value of roughness. Table 2 shows the roughness of GA coating surfaces with parameters of $R_{\mathrm{a}}=$ mean value of roughness, $R_{\max }=$ maximum value of roughness and PPC $=$ peak per centimeter measured at the GA coating surface in Figs. 5(a) through 5(f).

Figure 7 shows the X-ray diffraction patterns obtained from the GA coatings in Fig. 5, i.e., Fig. 7(a) from the coating surface mostly consisting of the columnar phase in Figs. 5(a), 7(b) from the granular phase in Figs. 5(c) and 


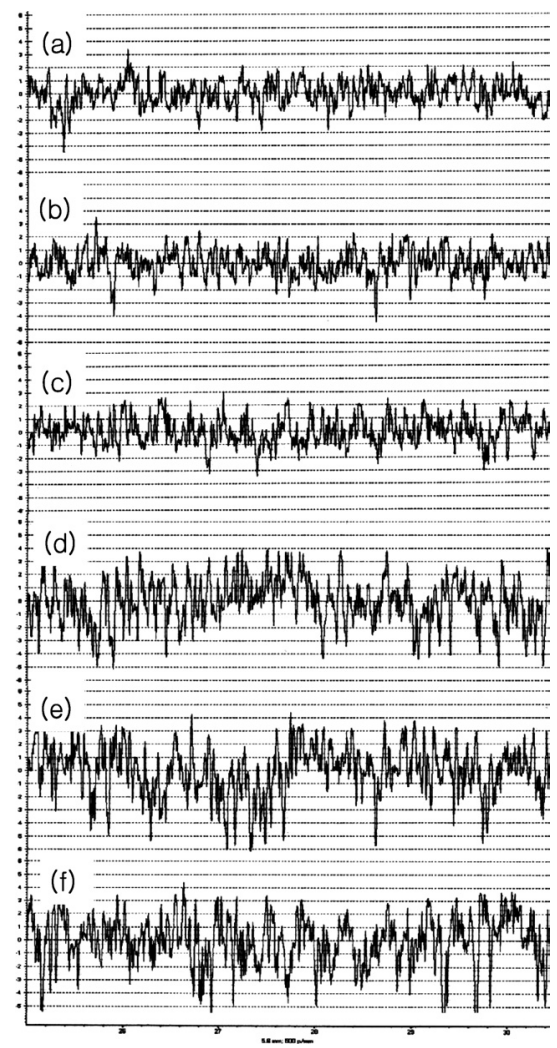

Fig. 6. Two-dimensional roughness profiles measured from the surface of GA coating in Fig. 5; i.e., (a) $0.125 \mathrm{wt} \% \mathrm{Al}$ and $485^{\circ} \mathrm{C}$, (b) $0.135 \mathrm{wt} \% \mathrm{Al}$ and $510^{\circ} \mathrm{C}$, (c) $0.145 \mathrm{wt} \%$ $\mathrm{Al}$ and $525^{\circ} \mathrm{C}$, (d) $0.155 \mathrm{wt} \% \mathrm{Al}$ and $540^{\circ} \mathrm{C}$, (e) 0.160 wt $\% \mathrm{Al}$ and $560^{\circ} \mathrm{C}$ and (f) $0.165 \mathrm{wt} \% \mathrm{Al}$ and $605^{\circ} \mathrm{C}$, respectively.

Table 2. The $R_{\mathrm{a}}=$ mean value of roughness, $R_{\max }=$ maximum value of roughness and $\mathrm{PPC}=$ peak per $\mathrm{cm}$ measured at the surface of GA coating in Fig. 5.

\begin{tabular}{|c|c|c|c|c|c|c|}
\hline $\begin{array}{c}\text { Sample No. } \\
\mathrm{Al}(\mathrm{wt} \%)\end{array}$ & $\begin{array}{c}(\mathrm{a}) \\
0.125\end{array}$ & $\begin{array}{c}(\mathrm{b}) \\
0.135\end{array}$ & $\begin{array}{c}(\mathrm{c}) \\
0.145\end{array}$ & $\begin{array}{c}(\mathrm{d}) \\
0.150\end{array}$ & $\begin{array}{c}(\mathrm{e}) \\
0.155\end{array}$ & $\begin{array}{c}\text { (f) } \\
0.160\end{array}$ \\
\hline $\mathrm{R}_{\mathrm{a}}$ & 0.75 & 0.78 & 0.83 & 1.22 & 1.31 & 1.37 \\
\hline $\mathrm{R}_{\max }$ & 4.93 & 6.62 & 6.13 & 7.91 & 9.38 & 10.18 \\
\hline $\mathrm{PPC}$ & 142 & 144 & 167 & 152 & 159 & 139 \\
\hline
\end{tabular}

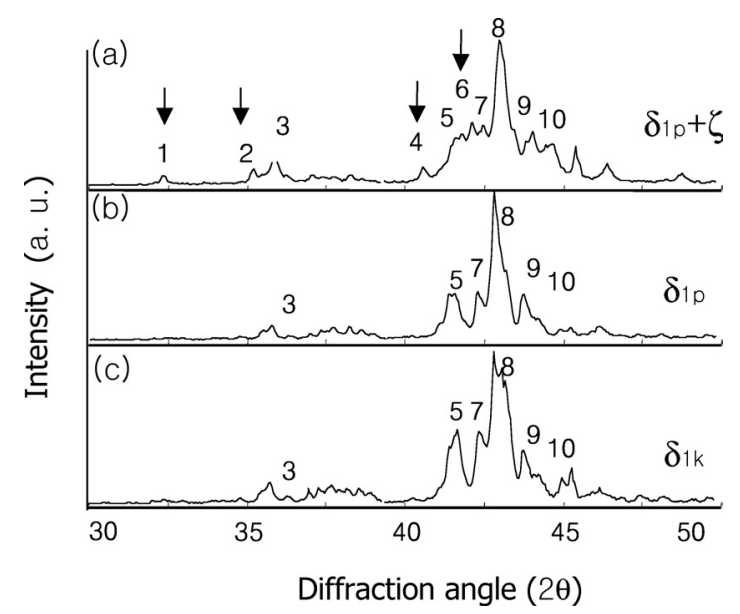

Fig. 7. The X-ray diffraction patterns obtained from the GA coating in Fig. 5. (a) analyzed from the columnar phase in Figs. 5(a), (b) from the granular phase in Fig. 5(c) and (c) from the faceted and/or pan-cake phase in Fig. 5(f), respectively.
Table 3. Indexing of the X-ray diffraction patterns. They are in good consistency with that of the $\delta_{1}$ and $\zeta$ phases.

\begin{tabular}{|l|l|l|l|}
\hline No & $\mathrm{d} \mathrm{m}\left(\mathrm{A}^{\circ}\right)^{*}$ & $\mathrm{~d}(\mathrm{cal})$. & Phase \\
\hline 1 & 2.763 & 2.769 & $\zeta(\overline{2} 21)$ \\
\hline 2 & 2.556 & 2.558 & $\zeta(\overline{4} 01)$ \\
\hline 3 & 2.521 & 2.526 & $\delta_{1}(233)$ \\
\hline 4 & 2.246 & 2.248 & $\zeta(\overline{131})$ \\
\hline 5 & 2.198 & 2.199 & $\delta_{1}(503)$ \\
\hline 6 & 2.184 & 2.188 & $\zeta(321)$ \\
\hline 7 & 2.158 & $2.160,2.160$ & $\zeta(\overline{3} 12), \delta_{1}(1412)$ \\
\hline 8 & 2.134 & 2.136 & $\delta_{1}(330)$ \\
\hline 9 & 2.121 & $2.123,2.122$ & $\zeta(\overline{4} 21), \delta_{1}(3215)$ \\
\hline 10 & 2.092 & 2.095 & $\delta_{1}(241)$ \\
\hline
\end{tabular}

7(c) from the faceted phase in Fig. 5(f), respectively. In Fig.

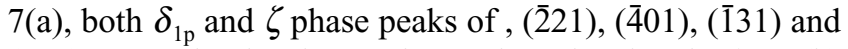
(321) were clearly observed. On the other hand, Fig. 7(b) obtained from granular phase in Fig. 5(c) exhibited only $\delta_{1 \mathrm{p}}$ diffraction peaks. This fact indicates that the columnar phase in Fig. 5(a) is identified as $\zeta$ phase, while granular phase in Fig. 5(c) is identified as $\delta_{1 \mathrm{p}}$ phases, respectively. Interestingly, there was no difference in X-ray diffraction patterns between granular phase in Fig. 7(b) and faceted phase in Fig. 7(c), respectively, despite that their morphology were significantly different. This can be well explained by the electron diffraction results that ordering took place in $\delta_{1 \mathrm{k}}$ phase, while no ordering took place in $\delta_{1 \mathrm{k}}$ phase, and there is no difference within the resolution of X-ray patterns. ${ }^{3)}$ Furthermore, it can be said that the powdering behavior of the GA coating becomes poorer with increasing the amount of faceted $\delta_{1 \mathrm{k}}$ phase. i.e., mechanical test obtained from $\mathrm{Fe}-\mathrm{Zn}$ single phase showed that faceted $\delta_{1 \mathrm{k}}$ phase is rather brittle and has higher Vickers micro-hardness in comparison with granular $\delta_{1 \mathrm{p}}$ phase. ${ }^{7)}$ Table 3 shows the indexing result of the X-ray diffraction patterns in Fig. 7.

Figures 8(a) through 8(f) show cross-sectional SEM images corresponding to the plan-view in Fig. 5. The thickness of GA coating was measured to be around $10 \mu \mathrm{m}$. The dark band at the coating/substrate interface is the most brittle $\Gamma$ phase in the Fe-Zn system. The cracks in GA coating must have been introduced during the sample preparation of mounting and polishing because they were not observed in the plan-view observation where no strain had been applied during sample preparation. Table 4 shows the thickness of $\Gamma$ phase as measured in Fig. 8, amount of powdering and index of flaking. As shown in Figs. 8(a)-8(c), below $0.145 \mathrm{wt} \%$, the thickness of $\Gamma$ phase and amount of powdering increased with increasing the $\mathrm{Al}$ content and galvannealing temperature. Powdering properties can be explained in terms of the $\Gamma$ thickness. However, this is not the case in the sample prepared above $0.165 \mathrm{wt} \% \mathrm{Al}$ at $600^{\circ} \mathrm{C}$ as shown in Fig. 8(f). High powdering value measured although the thickness of $\Gamma$ phase is thin in comparison with the samples produced by low $\mathrm{Al}$ content. This fact indicates that the amount of powdering depends not only on the wellaccepted $\Gamma$ thickness but also on the existence of faceted $\delta_{1 \mathrm{p}}$ phases in GA coating. On the other hand, it has been well accepted that flaking properties related to the chipping-resistance of GA coating after painting is independent to the powdering properties. ${ }^{20)}$ It attributes from the fact 


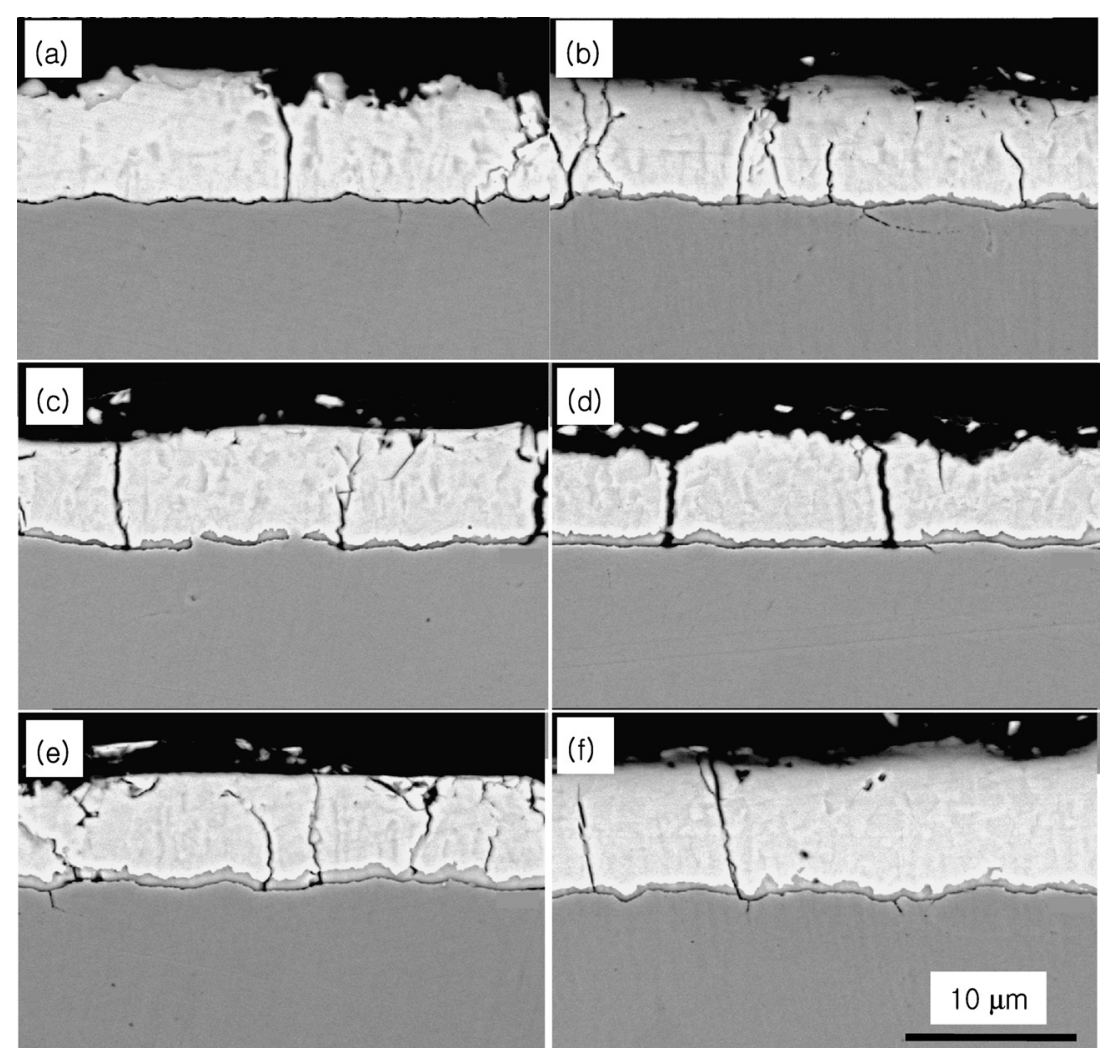

Fig. 8. Cross-sectional SEM images corresponding to the plan-view in Fig. 5; i.e., (a) $0.125 \mathrm{wt} \% \mathrm{Al}$ and $485^{\circ} \mathrm{C}$, (b) $0.135 \mathrm{wt} \% \mathrm{Al}$ and $510^{\circ} \mathrm{C}$, (c) $0.145 \mathrm{wt} \% \mathrm{Al}$ and $525^{\circ} \mathrm{C}$, (d) $0.155 \mathrm{wt} \% \mathrm{Al}$ and $540^{\circ} \mathrm{C}$, (e) $0.160 \mathrm{wt} \% \mathrm{Al}$ and $560^{\circ} \mathrm{C}$ and (f) $0.165 \mathrm{wt} \% \mathrm{Al}$ and $605^{\circ} \mathrm{C}$, respectively.

Table 4. Relationship between the amount of defoliation and $\Gamma$ layer thickness in GA coating.

\begin{tabular}{|c|c|c|c|c|c|c|}
\hline $\begin{array}{c}\text { Sample No. } \\
\mathrm{Al}(\mathrm{wt} \%)\end{array}$ & $\begin{array}{c}\text { (a) } \\
0.125\end{array}$ & $\begin{array}{c}\text { (b) } \\
0.135\end{array}$ & $\begin{array}{c}\text { (c) } \\
0.145\end{array}$ & $\begin{array}{c}\text { (d) } \\
0.150\end{array}$ & $\begin{array}{c}(\mathrm{e}) \\
0.155\end{array}$ & $\begin{array}{c}(\mathrm{f}) \\
0.160\end{array}$ \\
\hline Powdering $\left(\mathrm{mg} / \mathrm{m}^{2}\right)$ & 8.0 & 14.8 & 18.2 & 16.2 & 79.9 & 88.5 \\
\hline Flaking (index) & 1 & 1 & 3 & 1 & 5 & 5 \\
\hline$\Gamma$ thickness $(\mathrm{nm})$ & 350 & 579 & 631 & 737 & 947 & 634 \\
\hline
\end{tabular}

that powdering and flaking properties are largely affected by compression and shear stress, respectively. ${ }^{8,9,21)}$ In particular, high density of craters in Figs. 5(d)-5(e) was turned out to be effective to suppress the flaking index as it works as an anchor for propagating the crack along the coating/substrate interface. Above $0.160 \mathrm{wt} \% \mathrm{Al}$ and $550^{\circ} \mathrm{C}$, GA coating with higher $\mathrm{Fe} \%$ has the poorer powdering and flaking properties.

The most important interest for automotive exposed GA panel is to optimize the powdering and flaking properties during press forming. ${ }^{8)}$ The defoliation of coating affects the corrosion resistance and the workability of forming dies. In Figs. 3 and 4, it is known that the powdering depends substantially on the Al content, galvannealing temperature and temperature of zinc bath. Powdering increased linearly with increasing the galvannealing temperature at low Al content in zinc bath. Although it is generally accepted that the amount of powdering increases as a function of the $\Gamma$ thickness formed at coating/substrate interface when other conditions are constantly maintained, in the present study, the correlation between the powdering and $\Gamma$ thickness does not exist as shown in Table 4. This can be well explained by the fact that the variation of $\mathrm{Al}$ content in zinc bath affects the formation kinetics of $\mathrm{Fe}-\mathrm{Al}$ inhibition layer and subsequent $\mathrm{Fe}-\mathrm{Zn}$ alloy reaction. ${ }^{16)}$ By increasing the $\mathrm{Al}$ content, rather thick and dense $\mathrm{Fe}-\mathrm{Al}$ inhibition layer formed at the molten zinc/substrate interface. Al concentration in inhibition layer increased and gave rise to the retardation of $\mathrm{Fe}-\mathrm{Zn}$ alloy nucleation and growth. Below $0.145 \mathrm{wt} \%$, inhibition layer disappeared soon by the interdiffusion of $\mathrm{Zn}$ and $\mathrm{Fe}$ atoms and, at first stage of galvannealing, ductile $\zeta$ phase homogeneously formed at the coating/substrate interface. Finally, GA coating is characterized by thin $\Gamma$ phase (below $0.6 \mu \mathrm{m}$ ) and small amount of $\zeta$ layer near the coating surface as shown in Figs. 8(a) and 8(b) which shows good powdering properties, namely $8 \mathrm{mg} / \mathrm{m}^{2}$ and $15 \mathrm{mg} / \mathrm{m}^{2}$. By increasing the galvannealing temperature a few degrees, the $\Gamma$ thickness increased to $0.7 \mu \mathrm{m}$ and $\zeta$ phase disappeared at the coating surface and resulted in the increase of the powdering to $18 \mathrm{mg} / \mathrm{m}^{2}$. Above $0.155 \mathrm{wt} \%$, rather thick and dense inhibition layer retarded the nucleation and growth of $\mathrm{Fe}-\mathrm{Zn}$ alloy and $\zeta$ phase which is preferentially formed at the triple grain boundaries of ferrite according to the out-burst reaction. The Fe- $\mathrm{Zn}$ reaction proceeded inhomogeneously in comparison with thin $\mathrm{Al}$ inhibition layer and many craters related to the reaction of out-burst was frequently observed as shown in Figs. 5(d)-5(f). In industrial CGL, during the GI to GA transition, the galvannealing has to be performed around $0.15-0.16 \mathrm{wt} \%$. To prevent the appearance of underalloying, the galvannealing temperature has to be increased over $600^{\circ} \mathrm{C}$. The promoted reaction of $\mathrm{Fe}-\mathrm{Zn}$ at high galvannealing temperature followed by extinction of thick 
$\mathrm{Fe}-\mathrm{Al}$ inhibition layer resulted in the growth of faceted $\mathrm{d}_{1 \mathrm{k}}$ phase. The (0001) basal plane of hexagonal $\delta_{1 \mathrm{k}}$ phase has low free energy and it should be nucleated parallel to the coating/substrate interface as shown in Fig. 5(e). The appearance of faceted $\delta_{1 \mathrm{k}}$ phase on GA coating may contribute to the increase of powdering, although the $\Gamma$ thickness is not so much high as shown in Fig. 8(f). It is also known that appearance of faceted $\delta_{1 \mathrm{k}}$ phase on GA coating surface deteriorated the flaking properties.

\section{Conclusions}

Optical microscopy, SEM and X-ray observations and mechanical test were used to clarify the correlation between microstructure and defoliation of GA coating in $\mathrm{Ti}+\mathrm{Nb}$ interstitial free steel sheets for automotive exposed panels during press forming. Following results were obtained.

(1) Between $0.125-0.145 \mathrm{wt} \% \mathrm{Al}$, the amount of powdering increased with increasing the Al content and galvannealing temperature. However, there existed no correlation between the $\Gamma$ thickness and galvannealing temperature.

(2) Below $0.135 \mathrm{wt} \% \mathrm{Al}$ at the galvannealing temperature of $510^{\circ} \mathrm{C}$, surface of GA coating composed of the mixture of columnar $\zeta$ and granular $\delta_{1 \mathrm{p}}$ phases. The characteristics of coating were favored for automotive panel criteria, i.e., $\Gamma$ thickness of less than $0.6 \mu \mathrm{m}$, powdering amount of less than $20 \mathrm{mg} / \mathrm{m}^{2}$ and the roughness, $R_{\mathrm{a}}$, of $0.75-0.83 \mu \mathrm{m}$.

(3) Above $0.160 \mathrm{wt} \% \mathrm{Al}$ with the galvannealing temperature of $560^{\circ} \mathrm{C}$, surface of GA coating composed of the mixture of granular $\delta_{1 \mathrm{p}}$ and faceted $\delta_{1 \mathrm{k}}$ phase. GA coatings were not suitable for automotive press forming, i.e., the $\Gamma$ thickness of above $0.7 \mu \mathrm{m}$, powdering amount of more than $30 \mathrm{mg} / \mathrm{m}^{2}$ and the roughness, $R_{\mathrm{a}}$, of $1.22-1.37 \mu \mathrm{m}$.

(4) The appearance of faceted $\delta_{1 \mathrm{k}}$ phase approximately $10 \mu \mathrm{m}$ in size deteriorated the powdering and flaking properties of GA coating during deep drawing and U-bend tests.

\section{Acknowledgments}

The author thanks Mr. Jung-Wu Lee of POSCO Kwang- yang works for his help during the present study. He is also grateful to Drs. Doo-Jin Baik, Jong-Sang Kim and JinHwan Chung of POSCO technical Lab. and Prof. Hiroyasu Saka of Nagoya University for their stimulating discussion.

\section{REFERENCES}

1) T. Sakiyama, M. Ichigawa, Z. Saito and Y. Matsuzaki: CAMP-ISIJ, 3 (1990), 1508.

2) J. Guth and J. M. Mataigne: Proc. of GALVATECH', Iron and Steel Society, Warrendale, PA, (1995), 709

3) M. H. Hong and H. Saka: Scr. Mater, 36 (1997), 1423.

4) T. Kato, M. H. Hong, K. Nunome, K. Sasaki, K. Kuroda and H. Saka: Thin Solid Film, 319 (1998), 132.

5) H. Saka, T. Kato and M. H. Hong: J. Surf. Finishing Soc. Jpn., 51 (2000), 568.

6) M. H. Hong and H. Saka: Philos. Mag., A74 (1996), 509.

7) M. H. Hong and H. Saka: Acta Mater., 45 (1997), 4225.

8) A. Okamoto: Recent Progress and Future Prospects in Steel Sheets and Surface Treated Steel Sheets, ISIJ, Tokyo, (1998), 31.

9) A. R. Marder: Prog. Mat. Sci., 45 (2000), 191.

10) B. Dauby, P. Vankeleffe and S. Feron: Proc. of GALVATECH'95, Iron and Steel Society, Warrendale, PA, (1995), 717.

11) E. Mcdevitt, Y. Morimoto and M. Meshii: ISIJ Int., 37 (1997), 776.

12) Y. Morimoto, E. Mcdevitt and M. Meshii: ISIJ Int., 37 (1997), 906.

13) G. J. Harvey and P. D. Mercer: Metall. Trans., 4 (1973), 619.

14) C. S. Lin and M. Meshii: Metall. Mater. Trans. B, 25B (1994), 721.

15) D. Dubois: Proc. of GALVATECH'01, ed. by M. Lamberights, Verlag Stahleisen, Düsseldorf, (2001), 453.

16) S. Gomi, C. Kato, T. Fujimura and K. Mochizuki: Zinc-Based Steel Coating Systems-Production and Performance, ed. by F. E. Goodwin, TMS, Warrendale, PA, (1998), 147.

17) A. Taniyama, M. Arai, T. Takayama and M. Sato: Proc. of GALVATECH'04, AIST, Warrendale, PA, (2004), 501.

18) N. Y. Tang: Metall. Trans. B, 30B, (1999), 144.

19) S. Yamaguchi, H. Makino, A. Sakatoku and Y. Iguchi: Proc. of GALVATECH'95, Iron and Steel Society, Warrendale, PA, (1995), 647.

20) A. Van der Heiden, A. J. C. Burghardt, W. Van Koesveld, E. B. Perlstein and M. G. J. Spangers: The Physical Metallurgy of Zinc Coated Steel, TMS annual meeting, TMS, Warrendale, PA, (1994), 251.

21) M. Arai, T. Nakamori, Y. Adachi and T. Utsugi: CAMP-ISIJ, 5 (1992), 1649. 